\title{
ВПЛИВ МЕЛАТОНІНУ НА АНТИОКСИДАНТНУ СИСТЕМУ ПЕЧІНКИ ЩУРІВ ПРИ ЕКСПЕРИМЕНТАЛЬНІЙ НЕФРОПАТІЇ
}

\section{Вплив мелатоніну на антиоксидантну систему печінки щурів при експериментальній нефропатії І. О. Коляник, І. В. Геруш}

Буковинський державний медичний університет, м. Чернівці

Резюме. Ураження нирок призводить до ускладнення багатьох соматичних захворювань і підвищує ризик смерті у пацієнтів. Це зумовлює необхідність пошуку засобів ефрективної та безпечної фрармакологічної корекції нефропатій різної етіології. Печінка та нирки відіграють важливу роль також у знешкодженні ксенобіотиків, тому вони більш схильні до окиснювальних ушкоджень. Мелатонін - гормон епіфріза, який володіє протизапальними та антиоксидантними властивостями. Доцільним є дослідження його ефректів на антиоксидантну систему печінки при захворюваннях нирок.

Мета дослідження - оцінити вплив мелатоніну на антиоксидантну систему печінки щурів при експериментальній нефрропатії.

Методи і методи. Експеримент проведено на 127 нелінійних щурах-самцях масою 0,16-0,18 ке. Експериментальну нефропатію моделювали за допомогою одноразового внутрішньочеревного введення фролієвої кислоти в дозі 250 мг/кг маси тіла. Мелатонін вводили інтрагастрально упродовж 3-х та 7-ми днів після моделювання нефропатії в дозі 10 мг/ке. Стан антиоксидантної системи печінки оцінювали за показниками активності SOD, каталази, GP, GST та вмісту відновленого глутатіону в постмітохондріальній фрракції печінки.

Результати. У печінці тварин з експериментальною нефропатією спостерігали суттєві порушення досліджуваних показників антиоксидантної системи. Так, активність GP, GST, вміст відновленого глутатіону знижувалась, а активність SOD та каталази зростала в печінці щурів із нефропатією на 3 добу експерименту порівняно з аналогічними показниками контрольної групи. Введення мелатоніну за умов нефрропатії сприяло нормалізації активності SOD, каталази, GST та вмісту відновленого глутатіону на 7 добу експерименту, хоча активність GP залишалася зниженою.

Висновки. У тварин з експериментальною нефрропатією спостерігається дисбаланс показників антиоксидантної системи, що, ймовірно, зумовлено посиленим вільнорадикальним ушкодженням біомолекул. Введення мелатоніну упродовж 7 днів сприяє норма-
Melatonin effect on the liver antioxidant system of rats with experimental nephropathy

I. O. Kolianyk, I. V. Gerush

Bukovinian State Medical University, Chernivtsi

e-mail: gerushiv@ukr.net

Summary. Kidney lesion results in complications of many somatic diseases and increases the risk of death of patients determining the necessity to find means of effective and safe pharmacological correction of nephropathy of various etiologies. The liver and kidneys play an important role in neutralization of xenobiotics, therefore they are more inclined to oxidative damage. Melatonin is a hormone secreted by the pineal gland possessing anti-inflammatory and anti-oxidant properties. Examination of its effects produced on the antioxidant liver system in case of kidney diseases is reasonable.

The aim of the study - to assess melatonin effect on the liver antioxidant system of rats with experimental nephropathy.

Materials and Methods. The experiment was conducted on 127 nonlinear male rats with the body weight of $0.16-0.18 \mathrm{~kg}$. Experimental nephropathy was simulated by means of a single injection of folic acid into the peritoneum in the dose of $250 \mathrm{mg} / \mathrm{kg}$ of the body weight. Melatonin was introduced into the stomach during 3 and 7 days after nephropathy simulation in the dose of $10 \mathrm{mg} /$ $\mathrm{kg}$. The state of the liver antioxidant system was assessed by the parameters of SOD, catalase, GP, GST activity and the content of reduced glutathione in the post-mitochondrial liver fraction.

Results. Considerable disorders of the antioxidant system examined parameters were found in the liver of animals with experimental nephropathy. Thus, GP, GST activity, the content of reduced glutathione decreased, and the activity of SOD and catalase in the liver of rats with nephropathy increased on the $3^{d}$ day of experiment versus similar parameters of the control group. Melatonin introduction under conditions of nephropathy promoted normalizing SOD, catalase, GST activity and the content of reduced glutathione on the $7^{\text {th }}$ day of the experiment, though GP activity remained reduced.

Conclusions. Imbalance of the antioxidant system parameters is found in animals with experimental nephropathy, which might be caused by intensified free radical damage of the biomolecules. Melatonin introduction during 7 days promotes normalizing of the 
лізації показників антиоксидантної системи у печінці щурів із нефропатією, що, ймовірно, зумовлено його здатністю безпосередньо знешкоджувати токсичні сполуки й активувати антиоксидантні ензими.

Ключові слова: експериментальна нефропатія; антиоксидантна система; печінка; мелатонін; фолієва кислота; сОД; каталаза; глутатіон.

\section{ВСТУП}

Сьогодні в світі гостре ушкодження нирок і, як наслідок - смертність, залишається на високому рівні та становить приблизно 20-75\%. Високий рівень захворюваності та смертності пов'язаний також із поширеністю COVID-19 в усьому світі, що викликає тяжкий гострий респіраторний синдром. У більшості хворих зростає кількість позалегеневих ускладнень різних органів та систем, у тому числі й нирок. Частота гострого ушкодження нирок (ГУН) у пацієнтів, інфрікованих COVID-19, складає від 3 до $6 \%$, підвищуючись до 15-58 \% у хворих, які перебувають у критичному стані. У померлих частота виникнення ГУН значно вища та становить 53 \%. Науковці припускають, що ГУН корелює не лише з тяжкістю захворювання, а й має прогностичне значення [1].

Основою патогенезу ниркової патології $€$ розвиток оксидативного стресу, що супроводжується оксидантно-антиоксидантним дисбалансом, і як наслідок - ураження печінки, - головного детоксикаційного органа.

Потреба у засобах ефрективної та безпечної фрармакологічної корекції нефрропатій різної етіології вимагає від світової фрармацевтичної промисловості розширення напрямків у цій сорері. Недостатні методи лікування зумовлюють необхідність для удосконалення фрармакотерапії та впровадження інших, ефрективніших засобів нефропротекції, які впливатимуть на етіологічний, патогенетичний i симптоматичний компоненти захворювання [2].

Мелатонін - гормон епіфріза, який володіє протизапальними та антиоксидантними властивостями. Тому доцільним є дослідження його ефектів на антиоксидантну систему печінки при захворюваннях нирок. Мелатонін відомий як есективний «перехоплювач» вільних радикалів. Окрім прямої дії на вільні радикали, мелатонін стимулює синтез глутатіону та підвищує рівень антиоксидантних фрерментів $[3,4]$. Також мелатонін підвищує активність I та IV мітохондріального комплексу дихального ланцюга, що запобігає «втечі» електронів та зменшує ризик виникнення оксидативного стресу [5].

3 огляду на вищезазначені дані, для дослідження були обрані ферменти, дія яких спрямована на посилення антиоксидантного захисту, індукцію мембранопротекторних та цитопротекторних механізмів у поєднанні з вираженою детоксикуючою активністю. antioxidant system parameters in the liver of rats with nephropathy, which might be stipulated by its ability to directly neutralize toxic compounds and activate antioxidant enzymes.

Key words: experimental nephropathy; antioxidant system; liver; melatonin; folic acid; SOD; catalase; glutathione.

Метою дослідження було оцінити вплив мелатоніну на антиоксидантну систему печінки щурів при експериментальній нефропатії.

\section{МАТЕРІАЛИ І МЕТОДИ}

Експериментальне дослідження виконано на 127 білих нелінійних щурах-самцях масою тіла 0,16-0,18 кг. Моделювання нефропатії здійснювали шляхом одноразового внутрішньочеревного введення фролієвої кислоти (Sigma-Aldrich, США) у дозі 250 мг/кг маси тіла [6]. Тварин поділили на 5 груп: перша - контрольні тварини; друга щури із змодельованою експериментальною нефрропатією (3 день); третя - тварини, яким на тлі моделювання експериментальної нефропатії щоденно вводили мелатонін (Sigma-Aldrich, США ) із розрахунку 10 мг/кг маси тіла внутрішньошлунково (3 день); четверта - щури із змодельованою нефрропатією (7 день); п'ята - тварини із експериментальною нефропатією, яким щоденно вводили мелатонін в дозі 10 мг/кг маси (7 день). Тварини перебували в умовах віварію зі сталим температурним режимом $\left(18-22{ }^{\circ} \mathrm{C}\right)$, відносній вологості повітря (50-55 \%) в окремих обмінних клітках у сформованих групах, на постійному збалансованому режимі харчування 3 вільним доступом до води та їжі. Всі дослідження виконано відповідно до положень Директиви Ради Європи 2010/63/ EU про захист тварин, що використовуються для наукової мети.

Для оцінки стану антиоксидантного захисту печінки визначали показники активності каталази [КФ 1.11.1.6] (КАТ) [7], супероксиддисмутази [КФ 1.15.1.1] (SOD) [8], глутатіонпероксидази [КФ 1.11.1.9] (GP) [9,10], глутатіон-S-трансорерази [КФ 2.5.1.18] (GST) [11] та вміст відновленого глутатіону (GSH) [12].

Рівень білка визначали за методом Лоурі [13]. Вимірювання проводили на спектрофротометрі Agilent Cary 60. Статистичну обробку отриманих даних проводили 3 використанням непараметричного критерію Вілкоксона. Достовірними вважали відмінності при р $\leq 0,05$.

\section{РЕЗУЛЬТАТИ Й ОБГОВОРЕННЯ}

Ми встановили (табл.), що експериментальна нефропатія призводить до підвищення активності супероксиддисмутази на 3-й день експерименту 
на 30,4 \% та активності каталази на 3 та 7 день на 24,9 \% та 19,4 \% відповідно, порівняно з групою контрольних тварин, і свідчить про активацію цих ензимів у відповідь на зростання АФК.

Антиоксидантні ензими, такі, як супероксиддисмутаза та каталаза перетворюють активні фрорми оксигену в більш стабільні молекули шляхом складного каскаду реакцій. Одним із найбільш ефективних внутрішньоклітинних ензимів $€$ SOD, яка каталізує реакцію дисмутації $\mathrm{O}_{2}^{-}$до $\mathrm{H}_{2} \mathrm{O}_{2}$, цим самим зменшуючи кількість супероксидних аніон-радикалів [14]. А каталаза здійснює перетворення $\mathrm{H}_{2} \mathrm{O}_{2}$ до води та оксигену. Обидва ензими, діючи синергічно, відіграють ключову роль у захисті клітин від окиснювального ушкодження та підтриманні клітинного окисно-відновлювального гомеостазу [15].

Глутатіон - ендогенний трипептид, є найпотужнішим антиоксидантом та детоксикантом завдяки реактивності SH-групи, яка, як сильний нуклеофіл, зв'язує електрофріли. Глутатіон бере участь у білковому та вуглеводневому обмінах, впливаючи на процеси гліколізу в тканинах та виявляючи гепатопротекторну дію.

Ми встановили зниження вмісту GSH на 33,6 \%, глутатіонпероксидазної активності на 11,6\%, глутатіон-S-трансореразної активності - на 22,7 \% на 3-й день виникнення нефропатії, та зниження вмісту GSH та активності GP на 7-й день у тварин 3 нефрропатією на 23,1 та 36,5 \% відповідно порівняно 3 контролем.

Глутатіонпероксидаза знешкоджує пероксид гідрогену та гідропероксиди ліпідів, але швидкість реакцій знешкодження цих сполук залежить від вмісту відновленого глутатіону в клітинах. Тому таке зниження активності GP може бути результатом зниженого вмісту GSH.

Глутатіон-S-трансорераза $є$ одним із основних ензимів глутатіонової системи, що забезпечує детоксикацію токсичних сполук. Як і GP, активність GST залежить від концентрації відновленого глутатіону, оскільки 3 цим ензимом кон'югують токсичні сполуки, в тому числі продукти пероксидного окиснення біополімерів, які утворюються в резуль- таті активації вільнорадикальних процесів. Відомо, що активність GP і GST найвищою $€$ в печінці, у зв'язку з провідною роллю даного органа в знешкодженні токсичних сполук [4].

Введення мелатоніну мало позитивний вплив на активність супероксиддисмутази та каталази, що проявлялося в зниженні цих показників на 19,4 та 18,4 \% відповідно на 3-й день експерименту порівняно з показниками тварин із нефропатією. Також мало місце зниження активності каталази на 16,8 \% на 7-й день після введення мелатоніну порівняно $з$ показниками експериментальних тварин із нефропатією. Активність каталази досягала рівня контрольних тварин, що свідчить про потужні антиоксидантні властивості мелатоніну.

Ведення мелатоніну сприяло зростанню вмісту GSH як на 3-й, так і на 7-й день експерименту на 30,3 та 24,2 \% відповідно, порівняно з показниками тварин із нефропатією, що, ймовірно, свідчить про встановлення тіол-дисульфрідної рівноваги, яка необхідна для здійснення таких процесів, як фрункціонування мембранних структур і цитоскелета, клітинного поділу, регуляції активності гормонів. Встановлено, що мелатонін підвищував активність GP на 39,2 \% на 7-й день, порівняно з показниками тварин із нефропатією, однак все ще достовірно відрізнявся від показників контролю.

Використання екзогенних антиоксидантів сприяє нормалізації окисно-відновного балансу та зменшенню ушкодження ниркової тканини молекулами активних фрорм оксигену. Такий вплив мелатоніну на антиоксидантну систему може бути зумовлений тим, що мелатонін може легко проходити через клітинні мембрани, завдяки своїй високій ліофільності та гідрофрільності, цим самим безпосередньо впливаючи на рівень вільних радикалів, сприяючи зниженню окиснювального стресу. Або ж стимулюючи активність ряду антиоксидантних ензимів, у тому числі й ензимів синтезу глутатіону - важливого несерментативного низькомолекулярного антиоксиданту, таким чином синергічно взаємодіючи з ним [13]. Крім того, мелатонін здатен покращувати роботу дихального ланцюга мітохондрій, дозволяючи уникнути генерації вільних радикалів [16].

Таблиця. Активність показників антиоксидантної системи печінки щурів при експериментальній нефропатії

\begin{tabular}{|c|c|c|c|c|c|}
\hline & $\begin{array}{c}\text { SOD, } \\
\text { Од/мг протеїну }\end{array}$ & $\begin{array}{c}\text { КАТ, } \\
\text { мкM/хв×г } \\
\text { протеїну }\end{array}$ & $\begin{array}{c}\text { GSH, } \\
\text { нмоль/мг } \\
\text { тканини }\end{array}$ & $\begin{array}{c}\mathrm{GP}, \\
\text { нмоль/хв×мг } \\
\text { протеїну }\end{array}$ & $\begin{array}{c}\text { ГST, } \\
\text { нмоль/хв×мг } \\
\text { протеїну }\end{array}$ \\
\hline Контроль & $0,79 \pm 0,02$ & $35,16 \pm 1,34$ & $6,81 \pm 0,25$ & $169,8 \pm 7,2$ & $61,52 \pm 2,34$ \\
\hline Нефропатія, 3 день & $1,03 \pm 0,07^{*}$ & $43,93 \pm 1,79^{*}$ & $4,52 \pm 0,36^{*}$ & $150,1 \pm 7,9^{* *}$ & $47,55 \pm 1,99^{*}$ \\
\hline Несропатія+мелатонін, 3 день & $0,83 \pm 0,05^{\#}$ & $35,83 \pm 2,25^{\# \#}$ & $5,89 \pm 0,38 *$ *\# & $151,4 \pm 6,1^{* *}$ & $49,04 \pm 2,72^{*}$ \\
\hline Неоропатія, 7 день & $0,88 \pm 0,04$ & $41,98 \pm 2,90^{\star *}$ & $5,24 \pm 0,35^{*}$ & $107,7 \pm 9,9^{*}$ & $56,21 \pm 5,40$ \\
\hline Несропатія+мелатонін, 7 день & $0,82 \pm 0,05$ & $34,92 \pm 3,18^{\# \#}$ & $6,51 \pm 0,40^{\# \#}$ & $150,0 \pm 7,8^{\star *}, \# \#$ & $58,76 \pm 7,74$ \\
\hline
\end{tabular}

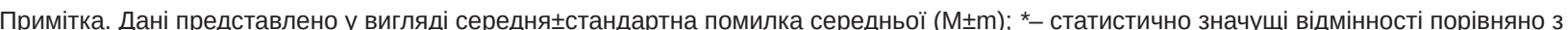
показниками контрольної групи тварин; \# - статистично значущі відмінності порівняно з показниками групи тварин із несропатією; р<0,01; ** - статистично значущі відмінності порівняно з показниками контрольної групи тварин; \#\# - статистично значущі відмінності порівняно 3 показниками групи тварин із нефропатією на 7-й день експерименту, p<0,05. 


\section{висновки}

Отже, при моделюванні несропатії фоолієвою кислотою, спостерігається дисбаланс показників антиоксидантної системи, що, ймовірно, зумовлено посиленим вільнорадикальним ушкодженням біомо- лекул. Введення мелатоніну упродовж 7 днів сприяє нормалізації показників антиоксидантної системи у печінці щурів із нефропатією, що зумовлено його здатністю безпосередньо знешкоджувати токсичні сполуки й активувати антиоксидантні ензими.

\section{СПИСОК ЛІТЕРАТУРИ}

1. Renal impairment and its impact on clinical outcomes inpatients who are critically ill with COVID-19: a multicentreobservational study / M. Gasparini, S. Khan, J. M. Patel [et al.] // Anaesthesia. - 2020.

2. Global epidemiology and outcomes of acute kidney injury / E. J. Hoste, J. A. Kellum, N. M. Selby [et al]. // Nat. Rev. Nephrol. - 2018. - No. 14 (10). - P. 607-625.

3. Melatonin potentials against viral infections including COVID-19: Current evidence and new findings / K. B. Juybari, M. H. Pourhanifeh, A. Hosseinzadeh [et al]. // Virus Res. - 2020. - No. 287. - P. 108-198.

4. Luhinich N. Effects of 7-day melatonin introduction on the hydrogen sulfide production and glutathione system in the liver of alloxan induced diabetic rats / N. Luhinich, I. Gerush // Georg. Med. News. - 2019. - No. 4 (289). P. $135-139$

5. Melatonin as a modulator of degenerative and regenerative signaling pathways in injured Retinal Ganglion Cells / K. B. Juybari, A. Hosseinzadeh, H. Ghaznavi [et al.] // Curr. Pharm. - 2019. - No. 25 (28). - P. 3057-3073.

6. Folic acid induces acute renal failure (ARF) by enhancing renal prooxidant state / A.Gupta, V. Puri, R. Sharma, R. Puri. // Exper. and Toxic. Pathol. - 2012. No. 64 (3) - P. 225

7. Метод определения активности каталазы / К. А. Королюк, Л. И. Иванова, И. Г. Майорова, В. Е. Токарев // Лаб. дело. - 1988. - № 1. - С. 16-19

8. Дубинина Е. Е. Активность и изоэнзимный спектр супероксиддисмутазы эритроцитов и плазмы крови человека / Е. Е. Дубинина, Л. Я. Сальникова, Л. Ф. Ефимова // Лаб. дело. - 1983. - № 10. - С. 30-33.

\section{REFERENCES}

1. Gasparini M, KhanS, Patel JM, ParekhD, Bangash MN, Stümpfle R, et al. Renal impairment and its impact on clinical outcomes inpatients who are critically ill with COVID-19: a multicentreobservational study. Anaesthesia. 2020. DOI: 10.1111/anae.15293.

2. Hoste EAJ, Kellum JA, Selby NM, Zarbock A, Palevsky PM, Bagshaw SM, et al. Global epidemiology and outcomes of acute kidney injury. Nat Rev Nephrol. 2018;14(10): 607-25. DOI: 10.1038/s41581-018-0052-0.

3. Bahrampour Juybari K, Pourhanifeh $\mathrm{MH}$, Hosseinzadeh A, Hemati K, Mehrzadi S. Melatonin potentials against viral infections including COVID-19: Current evidence and new findings. Virus Res. 2020;287: 108-98.

4. Luhinich N, Gerush I. Effects of 7-day melatonin introduction on the hydrogen sulfide production and glutathione system in the liver of alloxan induced diabetic rats. Georg Med News. 2019;289: 135-9.

5. Juybari KB, Hosseinzadeh A, Ghaznavi H, Kamali M, Sedaghat A, Mehrzadi S, et al. Melatonin as a modulator
9. Власова С. Н. Активность глутатионзависимых энзимов эритроцитов при хронических заболеваниях печени у детей / С. Н. Власова, Е. И. Шабулина, И. А. Перелегина // Лаб. дело. - 1990. - № 8. - С. 19-22.

10. Геруш І. В. Стан глутатіонової системи крові за умов експериментального виразкового ураження гастродуоденальної зони та дії настойки ехінацеї пурпурової / І. В. Геруш, І. Ф. Мещишен // Вісник проблем біол. та медицини. - 1998. - № 7. - С. 10-15.

11. The identity of glutathione S-transferase B with ligandin, a major binding protein of liver / W. H. Habig, M. J. Pabs, G. Fleischner [et al.] // Proceedings of the National Academy of Sciences. - 1974. - No. 71. - P. 3879 - 3882

12. Карпищенко А. И. Глутатионзависимая антиоксидантная система в некоторых тканях крыс в условиях острого отравления дихлорэтаном / А. И. Карпищенко, С. И. Глушков, В. В. Смирнов // Токсикологический вестник. - 1997. - С. 17-23.

13. Protein measurement with the Folin phenol reagent / O. H. Lowry, N. J. Rosebrough, A. L. Farr, R. J. Randall // J. Biol. Chem. - 1951. - No. 193 (1). - P. 265-275.

14. Hacışevki A. An overview of melatonin as an antioxidant molecule: A biochemical approach. / A. Hacışevki, B. Baba // Mol. Biol. Clin. Pharm. Approaches. - 2018. - P. 59-85.

15. Role of catalase in oxidative stress- and age-associated degenerative diseases / N. Ankita, Y. Liang-Jun, J. Chandan Kumar, D. Nilanjana. // Oxidative Medicine and Cellular Longevity. - 2019.

16. Mitochondrial dysfunction and oxidative stress in heart disease / J. N. Peoples, A. Saraf, N. Ghazal [et al]. // Exp. Mol. Med. - 2019. - No. 51. - P. 1-13.

of degenerative and regenerative signaling pathways in injured Retinal Ganglion Cells. Curr Pharm.2019;25(28): 3057-73. DOI:10.2174/1381612825666190829151314.

6. Gupta A, Puri V, Sharma R, Puri R. Folic acid induces acute renal failure (ARF) by enhancing renal prooxidant state. Exper and Toxic Pathol. 2012; 64(3): 225

7. Koroliuk, KA, Ivanova LI, Maiorova IG, Tokarev VE. [Method of determination of catalase activity]. Lab delo.1988;1: 16-9. Russian.

8. Dubynina EE, Salnykova LA, Efymova LF. [Activity and isoenzyme spectrum of erythrocyte superoxide dismutase and human blood plasma]. Lab delo.1983;10: 30-3. Russian.

9. Vlasova SN, Shabunina El, Perslegina IA. [The activity of glutathione-dependent erythrocyte enzymes in children with chronic liver diseases]. Lab delo. 1990;8: 19-22. Russian.

10. Gerush, IV. Meshchyshen, IF. [The state of the glutathione blood system under the conditions of experimental 
ulcerative lesions of the gastroduodenal zone and the action of tincture of Echinacea purpurea]. Visnyk problem biol ta medytsyny. 1998;7: 10-5.

11. Habig WH, Pabs MJ, Fleischner G. The identity of glutathione S-transferase B with ligandin, a major binding protein of liver. Proceedings of the National Academy of Sciences. 1974;71(10): 3879-82.

12. Karpishchenko AI, Glushkov SI, Smirnov VV. [Glutathione-dependent antioxidant system in some tissues of rats under conditions of acute poisoning with dichloroethane]. Toksikol vestn. 1997;3: 17-23. Russian.

13. Lowry $\mathrm{OH}$, Rosebrough NJ, Farr AL, Randall RJ. Protein measurement with the Folin phenol reagent. J Biol Chem. 1951;193(1): 265-75.
14. Hacışevki A, Baba B. An overview of melatonin as an antioxidant molecule: A biochemical approach. Mol Biol Clin Pharm Approaches. 2018; 59-85.

15. Ankita N, Liang-Jun Y, Chandan Kumar J, Nilanjana D. Role of Catalase in Oxidative Stress- and Age-Associated Degenerative Diseases. Oxidative Medicine and Cellular Longevity. 2019.

16. Peoples JN, Saraf A, Ghazal N, Pham TT, Kwong JQ. Mitochondrial dysfunction and oxidative stress in heart disease. Exp Mol Med. 2019;51: 1-13. 